THEME SECTION

\title{
Future marine zooplankton research-a perspective
}

\author{
Marine Zooplankton Colloquium 2* \\ Georgia Coastal Center for Education, Savannah, Georgia 31401, USA \\ 8-10 February 1999
}

\begin{abstract}
During the Second Marine Zooplankton Colloquium (MZC2) 3 issues were added to those developed $11 \mathrm{yr}$ ago during the First Marine Zooplankton Colloquium (MZC1). First, we focused on hot spots, i.e., locations where zooplankton occur in higher than regular abundance and/or operate at higher rates. We should be able to determine the processes leading to such aggregations and rates, and quantify their persistence. Second, information on the level of individual species, even of highly abundant ones, is limited. Concerted efforts should be undertaken with highly abundant to dominant species or genera (e.g., Oithona spp., Calanus spp., Oikopleura spp., Euphausia superba) to determine what governs their abundance and its variability. Third, zooplankton clearly influence biogeochemical cycling in the ocean, but our knowledge of the underlying processes remains fragmentary. Therefore a thorough assessment of variables that still need to be quantified is required to obtain an understanding of zooplankton contributions to biogeochemical cycling. Combining studies on the 7 issues from MZC1 with the 3 from MZC2 should eventually lead to a comprehensive understanding of (1) the mechanisms governing the abundance and existence of dominant zooplankton taxa, and (2) the control of biodiversity and biocomplexity, for example, in the tropical ocean where diversity is high. These recommendations come from an assemblage of chemical, physical and biological oceanographers with experience in major interdisciplinary studies, including modeling. These recommendations are intended to stimulate efforts within the oceanographic community to facilitate the development of predictive capabilities for major biological processes in the ocean.
\end{abstract}

KEY WORDS: Marine zooplankton · Significant research issues

${ }^{*}$ Participating scientists: U. Bathmann, M. H. Bundy, M. E. Clarke, T. J. Cowles, K. Daly, H. G. Dam, M. M. Dekshenieks, P. L. Donaghay, D. M. Gibson, D. J. Gifford, B. W. Hansen, D. K. Hartline, E. J. H. Head, E. E. Hofmann, R. R. Hopcroft, R. A. Jahnke, S. H. Jonasdottir, T. Kiørboe, G. S. Kleppel, J. M. Klinck, P. M. Kremer, M. R. Landry, R. F. Lee, P. H. Lenz, L. P. Madin, D. T. Manahan, M. G. Mazzocchi, D. J. McGillicuddy, C. B. Miller, J. R. Nelson, T. R. Osborn, G.-A. Paffenhöfer, R. E. Pieper, I. Prusova, M. R. Roman, S. Schiel, H. E. Seim, S. L. Smith, J. J. Torres, P. G. Verity, S. G. Wakeham, K. F. Wishner.

Corresponding author: G.-A. Paffenhöfer, Skidaway Institute of Oceanography, 10 Ocean Science Circle, Savannah, Georgia 31411, USA.E-mail: cmp@skio.peachnet.edu

\section{INTRODUCTION}

Marine zooplankton function at many levels in ocean food webs, as consumers, producers and prey. Ranging in size from microns (protozooplankton) to centimeters and meters (metazooplankton, including chains of Thaliacea), they are also major contributors to elemental cycling and vertical fluxes. Despite more than $100 \mathrm{yr}$ of research on these organisms, our knowledge of their ecological function in their natural environment has increased only modestly. Presently we possess methods to quantify at least the abundances and distributions of hard-bodied metazooplankton with 
accuracy, but have only coarse measures, acoustics for example, to locate dense aggregations and determine their temporal changes/variability. For neither protozoa nor metazooplankton have we definitive methods to determine key rates in situ, and most of the former remain inaccessible to study at the species level. Therefore it is not so much a lack of ideas but inadequate methodologies and instrumentation that limits the pace of advances in understanding marine zooplankton. Our ability to predict abundances and distributions, even of the most studied species, is still at an early stage. That realization resulted in the first Marine Zooplankton Colloquium (MZC1) in April 1988 and led to a second Marine Zooplankton Colloquium (MZC2) in February 1999. Several of the participants of MZC1, after consultations with colleagues, decided to organize MZC2, which addressed the following questions: (1)Which major issues have emerged as additional critical topics during the past decade in our field? (2) How can these issues be studied?

In the sections below, we first briefly consider the progress made on research issues initially raised in MZC1 (1989). While these issues remain significant for now and the near future, the bulk of this report focuses on 3 additional challenges that emerged in discussions at MZC2.

\section{PREVIOUS ISSUES}

The 7 research issues of MZC1 are listed in Table 1, each with several citations reflecting progress in that area over the past $12 \mathrm{yr}$. Neither the references selected for the table nor the brief comments below are meant to be complete. They are only meant to illustrate some of the ways in which advances have been realized. A definitive evaluation of recent progress in marine zooplankton ecology, requiring a more intensive review of all 7 issues, would be an appropriate way to mark the 20th anniversary of MZC1 in 2008.

Issue 1 (small-scale behaviors of individual zooplankters) was stimulated by our lack of understanding about how individual zooplankters behave and interact with other organisms at scales of relevance in their natural environment. Our citations of progress include in situ observations as well as experimental studies

Table 1. Issues from MZC 1: recent advances on these issues, and sources

\begin{tabular}{|c|c|c|}
\hline Issue & Observation & Source \\
\hline $\begin{array}{l}\text { (1) Small-scale } \\
\text { behavior of } \\
\text { individual } \\
\text { zooplankters }\end{array}$ & $\begin{array}{l}\text { In situ characterization of behavior of } 9 \text { copepod species } \\
\text { Behavior of ciliates to various stimuli } \\
\text { In situ behavior of Dioithona oculata } \\
\text { In situ preying of herring juveniles on Acartia } \\
\text { Mate location of copepods }\end{array}$ & $\begin{array}{l}\text { Kimoto et al. (1988) } \\
\text { Buskey \& Stoecker (1989) } \\
\text { Ambler et al. (1991) } \\
\text { Kils (1992) } \\
\text { Doall et al. (1998) }\end{array}$ \\
\hline $\begin{array}{l}\text { (2) Effects of environ- } \\
\text { mental variability on } \\
\text { individual physiology } \\
\text { and behavior }\end{array}$ & $\begin{array}{l}\text { In situ indirect effects of invertebrate predators on copepods } \\
\text { In situ indirect effects of predatory fish on copepods } \\
\text { Distribution of planktonic ciliates is affected by physical variables }\end{array}$ & $\begin{array}{l}\text { Neill (1990) } \\
\text { Bollens \& Frost (1991) } \\
\text { James \& Hall (1995) }\end{array}$ \\
\hline $\begin{array}{l}\text { (3) Relation of growth, } \\
\text { fecundity and } \\
\text { mortality to } \\
\text { environmental } \\
\text { conditions, past } \\
\text { and present }\end{array}$ & $\begin{array}{l}\text { Growth and reproduction of adult and juvenile copepods in situ } \\
\text { Fecundity etc. of Oithona davisae in relation to hydrographic variables } \\
\text { In situ mortality of Centropages abdominalis } \\
\text { Copepod egg production in relation to seston composition } \\
\text { Changes in in situ copepod reproduction }(3 \mathrm{mo}) \\
\text { Seasonal mortality of Oithona }\end{array}$ & $\begin{array}{l}\text { Peterson et al. (1991) } \\
\text { Uye \& Sano (1995) } \\
\text { Liang et al. (1996) } \\
\text { Jonasdottir et al. (1995) } \\
\text { Niehoff et al. (1999) } \\
\text { Nielsen et al. (1999) }\end{array}$ \\
\hline $\begin{array}{l}\text { (4) Definition } \\
\text { of nutritional } \\
\text { requirements }\end{array}$ & $\begin{array}{l}\text { Feeding on heterotrophs is seen as enhancing copepod condition } \\
\text { Food quality and quantity affect growth rates of ciliates } \\
\text { Calanoid copepods prefer heterotrophs as food over diatoms } \\
\text { Copepod reproduction varies with the phytoplankton taxon eaten } \\
\text { Aldehydes from diatoms affect copepod egg viability negatively } \\
\text { Aldehydes are produced by diatoms upon breakage }\end{array}$ & $\begin{array}{l}\text { Kleppel (1993) } \\
\text { Mischke (1994) } \\
\text { Fessenden \& Cowles (1994) } \\
\text { Ban et al. (1997) } \\
\text { Miralto et al. (1999) } \\
\text { Pohnert (2000) }\end{array}$ \\
\hline $\begin{array}{l}\text { (5) Long-term observa- } \\
\text { tions of population and } \\
\text { community dynamics } \\
\text { and variability }\end{array}$ & $\begin{array}{l}\text { Parallel trends of abundance of phytoplankton, zooplankton, and herring over } 30 \mathrm{yr} \\
\text { Ocean temperature increase is accompanied by zooplankton decline } \\
\text { Decrease in fish stocks results in zooplankton increase }(45 \mathrm{yr}) \\
\text { Daily variability of copepod in situ feeding over } 3 \text { mo }\end{array}$ & $\begin{array}{l}\text { Aebischer et al. (1990) } \\
\text { Roemmich \& McGowan (1995) } \\
\text { Verheye et al. (1998) } \\
\text { Irigoien et al. (1998) }\end{array}$ \\
\hline $\begin{array}{l}\text { (6) Significance of } \\
\text { species } \\
\text { identification }\end{array}$ & $\begin{array}{l}\text { Living species are identified by specific motion and live morphology } \\
\text { Automated image recognition by the VPR and new algorithms } \\
\text { Closely related species can be distinguished with molecular technology }\end{array}$ & $\begin{array}{l}\text { Paffenhofer et al. (1996) } \\
\text { Tang et al. (1998) } \\
\text { Lindeque et al. (1999) }\end{array}$ \\
\hline $\begin{array}{l}\text { (7) Biological-physical } \\
\text { model } \\
\text { development }\end{array}$ & $\begin{array}{l}\text { Distribution of cod and haddock juveniles } \\
\text { Three-dimensional biological-physical model } \\
\text { General overview of progress } \\
\text { Mechanisms of zooplankton behavior-species specific } \\
\text { Coupling of individual-based population dynamics model to a circulation model } \\
\text { General overview of progress }\end{array}$ & $\begin{array}{l}\text { Werner et al. (1993) } \\
\text { Moisan et al. (1996) } \\
\text { Hofmann \& Lascara (1998) } \\
\text { Carlotti \& Wolf (1998) } \\
\text { Miller et al. (1998) } \\
\text { Carlotti et al. (2000) }\end{array}$ \\
\hline
\end{tabular}


Table 2. MZC2: issues and steps to accomplish them

\begin{tabular}{ll} 
Issues & \multicolumn{1}{c}{ Needed steps } \\
\hline (1) Significance of zooplankton hot spots & $\begin{array}{l}\text { (1) Information on dimensions, longevity of and activities } \\
\text { in hot spots, and their variability; mechanisms resulting in } \\
\text { hot spots; significance of hot spots for communities; } \\
\text { methods to locate hot spots and observe them non-invasively }\end{array}$ \\
(2) Information on individual species & $\begin{array}{l}\text { (2) Quantifications on 3 levels (integrative): (i) environment } \\
\text { and population; (ii) organism, its life history, activities, }\end{array}$ \\
bioenergetics; (iii) on molecular levels biochemical \\
adaptation and genetics. Utilize biological-physical \\
modeling for Issues (1) and (2), including advanced data \\
assimilation methods, circulation-biological models, \\
species-specific and nested models \\
(3) Use new biomarkers to determine the fate of organic \\
matter; determine mechanisms of DOC production, and its \\
composition from various producers; develop nested \\
models with strong empirical input to understand \\
biogeochemical cycles in relation to food web interactions
\end{tabular}

(Table 1). Notable is the promising technology that enables in situ behavioral observations of individual copepods Acartia discaudata being preyed upon by individual juvenile herring, moving obliquely upwards as a school (Kils 1992).

Issue 2 (effects of environmental variability on individual physiology and behavior) stemmed from several studies suggesting that zooplankton behaviors respond more to the magnitude of variance of the conditions encountered, rather than their average. Although this issue has not received a major amount of research attention, demonstrated behavioral responses include the almost immediate response of Acartia hudsonica to the introduction of predatory fish into enclosures (Bollens \& Frost 1991).

Issue 3 (relationship of growth, fecundity and mortality to environmental conditions, past and present) has received considerable attention. For example, Peterson et al. (1991) revealed how to obtain environmentally realistic rates of growth and reproduction of copepods. Obtaining comparable quantitative information on zooplankton mortality rates continues to be a major stumbling block, but the approach by Ohman \& Wood (1995) is promising. A comprehensive field study in a stable physical environment (e.g. with Calanus finmarchicus as a likely predator of Oithona) could provide quantification and some understanding of in situ mortality of a major copepod genus (Nielsen et al. 1999).

Issue 4 (definition of nutritional requirements) was addressed in a recent workshop (Kleppel 2001). We emphasize here recent observations on the effects of specific phytoplankton taxa on calanoid reproduction. For example, aldehydes produced by 3 different species of diatoms negatively affected calanoid egg viability (Miralto et al. 1999, Pohnert 2000); however, other phytoplankton may be nutritionally inadequate, rather than toxic to zooplankton (e.g. Kleppel 1993, Jonasdottir et al. 1995).

Issue 5 (long-term observations of population and community dynamics and variability) has been investigated in several field studies. Aebischer et al. (1990) showed the parallel trends of changes in the abundance of phytoplankton, zooplankton and herring off NE Great Britain over more than $30 \mathrm{yr}$, yet they stated 'The mechanisms behind the parallelism in trends remain unclear.' This paper and Roemmich \& McGowan (1995) illustrate the value of long-term observations. Major efforts and investments will be needed to conduct meaningful continuous long-term observations (B. W. Frost pers. comm., presenting Brodeur et al. 1998).

Issue 6 (significance of species identification) is progressing with the advent of new technology and data processing capability. Tang et al. (1998) showed indirectly that automated zooplankton species identification may be wishful thinking for the near future, especially when many similar species co-occur. However, using motion and the morphology of appendages can make it quite easy to separate even closely related species, if observations are made on living animals (Paffenhöfer et al. 1996). Taxonomic issues relating to openocean forms of marine protists was not explicitly noted in the MZC1 report but may ultimately be resolvable with the broader application of molecular methods.

Issue 7 (biological-physical model development) has progressed well in the $12 \mathrm{yr}$ since MZC1. Recent reviews by Hofmann \& Lascara (1998) and Carlotti et al. (2000) point towards the future. Virtual reality visualization methods are of particular significance when modeling the motions and behaviors of zooplankton. Model development will be addressed further below as part of the new issues raised at MZC2. 


\section{NEW ISSUES}

Of the 3 new issues identified at $\mathrm{MZC} 2$, the first relates to zooplankton hot spots, which in this context are defined as volumes of water characterized by enhanced biological activity and/or concentrations of zooplankton. Zooplankton hot spots are often dominated by 1 or only a few species as, for example, the dominance of zooplankton biomass and part of the food-web interactions by the copepod Calanoides carinatus during the Arabian Sea SW Monsoon (Smith et al. 1998). In order to unravel the functional repertoires and food-web influences of such dominant species, concerted efforts are needed at the species level, our second issue, ranging across different length and time scales. Biogeochemical cycling by zooplankton, including protozooplankton, is our third issue. It has been inadequately addressed in highly productive regions such as ocean margins. Efforts have been made to consider the bulk biomass and grazing properties of zooplankton in major JGOFS studies; however, the main roles and contributions of key dominant species have in most cases received inadequate attention. Therefore, the mechanisms of the contribution of abundant zooplankton species to biogeochemical cycling could not be reliably determined.

\section{Zooplankton hot spots}

For the purpose of this discussion, zooplankton hot spots are defined as ocean sites at which there is a recurrently pronounced zooplankton biomass signal and/or a critical rate process, with biomass or rate parameters well above the background mean. There is an implicit assumption of higher activity, although biomass is usually the signal. For example, an aggregation of inactive (diapausing) or senescent animals might not be considered a zooplankton hot spot per se, but could be an area of enhanced predatory activity. Often, high biomasses and/or rates are found at physical discontinuities or associated with episodic physical or environmental events, such as intermittent upwellings (e.g. Paffenhöfer et al. 1987). To be a zooplankton hot spot, a feature must be spatially identifiable over a significant period of time, and this may occur at several scales simultaneously. Mackas et al. (1985) provided examples of spatial relationships and longevities of phyto- and zooplankton patches related to physical oceanographic processes. Zooplankton hot spots may be present in shallow or deep water, nearshore or offshore.

\section{Zooplankton aggregations as locations of hot spots}

Zooplankton aggregations can occur on scales from mm to near $100 \mathrm{~km}$ (Fig. 1). Among the smallest hot spots are layers of heterotrophic flagellates moving continuously around a dead copepod nauplius (G.-A.P. pers. obs.). On a different scale, protozoa (Noctiluca miliaris) can form feeding webs that last for months (Omori \& Hamner 1982). In Kiel Bight, a dense $30 \mathrm{~cm}$ layer of 100 000 cells ml-1 of the tintinnid Stenosomella sp. was observed with in situ instrumentation (Kils 1990). Eventually, it was located by a school of juvenile herring and eaten within $25 \mathrm{~min}$. Copepod aggregations occur over a wide range of dimensions and periods of time (Fig. 1). Salps and doliolids can develop into patches extending over more than $100 \mathrm{~km}$ (Paffenhöfer et al. 1987). Scyphomedusae can form swarms from several $100 \mathrm{~m}$ to more than $10 \mathrm{~km}$ lasting from $1 \mathrm{~d}$ to $>1 \mathrm{wk}$ (Omori \& Hamner 1982, G.-A.P. pers. obs.).

Characterization and study of zooplankton hot spots

Specific questions and examples related to zooplankton hot spots include the following:

(1) What is the spatial extent, longevity, and variability of a hot spot with regard to individual species abundance or community organization? Although some 
information on spatial extent and longevity exists (Fig. 1), the results are over-generalized. Recent advances in instrumentation and deployment techniques have led to the discovery of thin layers of phytoplankton and zooplankton ranging in thickness from a few tens of $\mathrm{cm}$ to a few $\mathrm{m}$, extending horizontally for several $\mathrm{km}$ and persisting for $>24 \mathrm{~h}$ (Hanson \& Donaghay 1998, Holliday et al. 1998). Changes in temporal and spatial environmental features lead to variability in abundance, distribution and activity of zooplankton (MZC1 Issue 2). The extent of those features will be of special interest in attempting to understand the formation of zooplankton hot spots.

(2) What are the mechanisms that lead to the formation, maintenance and dispersion of zooplankton hot spots? For example, Price (1989) demonstrated that many specimens of the euphausiid Thysanoessa raschii returned to feed on a patch of phytoplankton (i.e. the phytoplankton provided a signal which resulted in the aggregation of the euphausiid). Reproduction responses to enhanced food can also provide a mechanism of patch formation, as illustrated by the calanoid copepod Temora turbinata in a phytoplankton-rich mass of upwelled water (Paffenhöfer et al. 1987). Calanoid copepods prefer strata of high primary productivity to those of highchlorophyll concentrations (Herman et al. 1981). Thus, food quality may to be more important than quantity (Kleppel 1993).

(3) Are zooplankton hot spots optimal habitats for some species of zooplankton and/or their predators? The study of Herman et al. (1981) seems to indicate that Calanus and other copepods can choose vertically the most favorable location. Are such hot spots indicators of optimal habitat for other kinds of species (i.e. fish that prey on the zooplankton)? For example, during the SCOPEX project, right whales migrated to the Cape Cod region each spring, apparently in need of finding and feeding upon very high concentrations of older life stages of a particular copepod species Calanus finmarchicus in order to sustain themselves (Wishner et al. 1995). The occurrence and specific locations of suitable zooplankton swarms and patches is a function of currents, weather, and water temperature.

(4) What are the impacts of zooplankton hot spots on individual species, including their life history strategies, behavior and physiology? A hot spot driven by food may only last as long as food is available (Price 1989). An individual copepod species may occupy different depth layers as it grows from early nauplius to adulthood (e.g. Miller 1993).

(5) What are the impacts of zooplankton hot spots on communities, including fisheries, biogeochemical cycles, and ecosystem function? Recruitment success of marine fish stocks is in part related to conditions where food concentrations exceed mean levels (e.g. Lasker 1975).

\section{Addressing the issue of zooplankton hot spots}

There are 3 major challenges related to observing and understanding the dynamics of zooplankton hot spots: finding, sampling/observing and modeling. The latter will be discussed in the following section on species-level issues. Finding a hot spot requires (1) knowledge of the physics and biology of the area to focus on a likely location, (2) the use of remote sensing tools, such as satellites, airplanes, and acoustic moorings, to monitor the area and detect an event or feature, and (3) specialized targeted sampling, such as fine-scale (cm) vertical profiles once the probable location has been identified.

Once found, the zooplankton hot spot needs to be studied with adaptive sampling, relative to the feature itself and its spatial and temporal development. Continuous studies over time are essential. Intermittent observations, such as one site visit per week or month, usually do not provide sufficient data on magnitude and longevity of in situ processes in dynamic regions. Rapid response is needed for temporally ephemeral events. It is vital to simultaneously quantify multiple variables of physics, chemistry, and biology with real-time visualization of data. Studies of rate processes and behavior, which require greater amounts of time to undertake, should be embedded within any synoptic program, but this may sometimes require a different sampling platform. Smaller-scale hot spots lasting seconds to minutes over centimeters to meters can be observed with noninvasive equipment, as shown by Kils (1992) using his ecoSCOPE. Long Term Ecosystem Research (LTER)-type efforts will be needed to determine the frequencies, duration, and rates of larger-scale hot spots. Larger-scale investigations are likely to be most successful in regions of simple physical circulation and predictable zooplankton assemblages; at the same time we need to strive to develop means to quantify activities on scales of basins. Continuous observations that combine both acoustical (Holliday et al. 1998) and optical measurements promise to provide valuable insights into taxonspecific and stage-specific positioning and aggregations (also MZC1 Issues 5 and 6). Our ability to understand how zooplankton actually function will depend to a large degree on technological advances in detecting identifiable targets at ecologically relevant scales.

The potential importance of zooplankton hot spots had been suggested previously by Haury et al. (1978). What is new is the availability of improved instrumentation and methodology for studying these features at the required spatial and temporal scales. Also, there is a greater appreciation of the potential importance of these hot spots, not merely as unique and interesting phenomena but as major contributors to totalecosystem structure and function. Zooplankton hot 
spots are critical to biogeochemical coupling, since much of the material flux may occur at very specific times and locations.

\section{Species level}

Within the context of a species-level focus 2 goals are essential to the future research on marine zooplankton: (1) understanding biodiversity and mechanisms of biological interactions, and (2) developing predictive modeling capability. The first goal is oriented towards curiosity-driven basic science. The second goal requires a research agenda facilitating appropriate environmental and biological data sets for models.

The working group recommended an integrative and concerted approach that includes multiple levels of biological analyses, from large-scale environments and populations to cellular and molecular levels (Fig. 2). The intent is to generate an understanding of a particular species and the associated relevant pro-

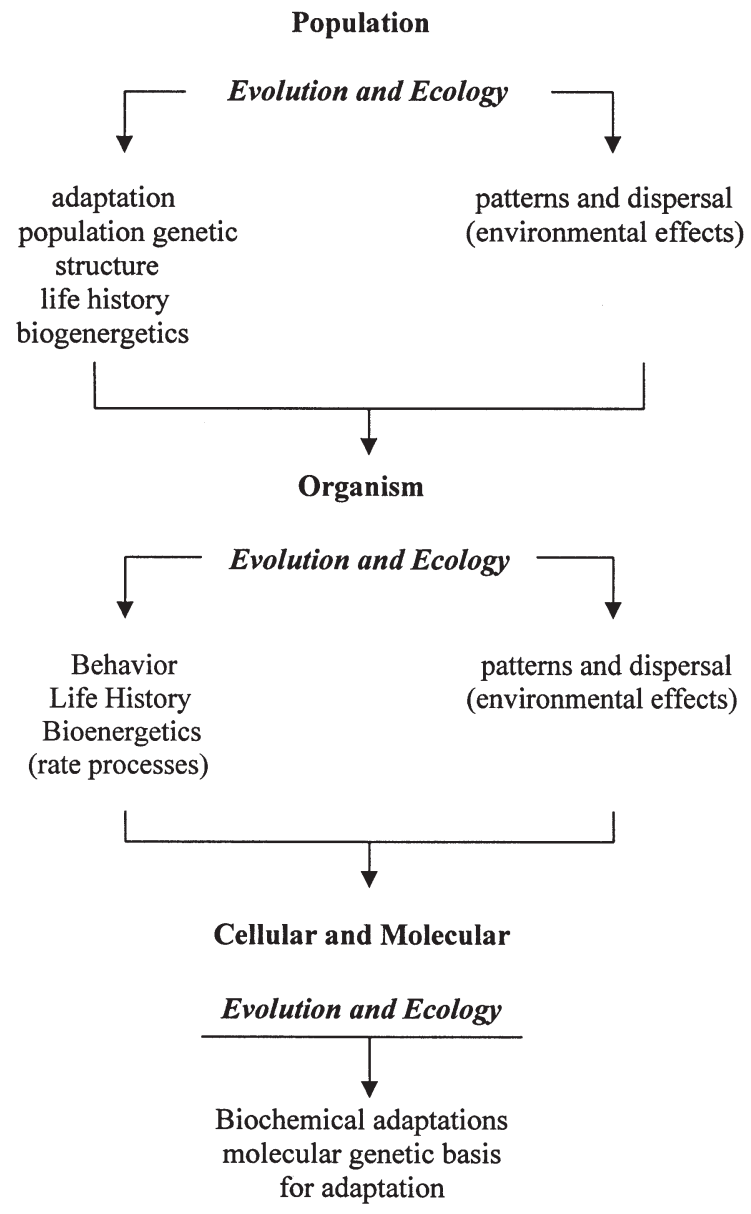

Fig. 2. Integration of species-level studies through 3 levels: population, organism, and cellular/molecular cesses over a wide range of space and time scales. The initial effort in marine zooplankton towards an understanding of function at the species level was made by Marshall \& Orr (1972), who dedicated their scientific careers to studies of the copepod Calanus finmarchicus.

\section{Characterization and study of the species-level approach}

At the level of the chemical, physical and biological environment and specific populations, the integrative approach focuses on ecology which includes patterns and dispersal, and evolution, including adaptation and genetic population structure, of a marine zooplankton species (Fig. 2). At the next level, individual organisms, the focus is on life histories, overwintering strategies, various behaviors including mating, predator avoidance and migrations, functional morphology including motion and feeding, and bioenergetics such as nutritional requirements and metabolic expenditures. At the cellular and molecular levels biochemical adaptations involving enzymes, and their genetic bases, are of major interest. The species-specific approach would provide an in-depth understanding for a limited number of marine zooplankton species to serve as a framework for considering ecosystem-level processes. Individual species are the basic evolutionary unit in the marine biota, and a species-level approach is an effective tool for studying organismenvironment interactions, as already considered in MZC1 (i.e. characterization of individual small-scale behaviors). This approach combines laboratory work and fieldwork to address basic science questions and to produce quantitative information for use in models based on realistic biology.

To follow this recommendation, the focus in future studies may be limited to one or a few abundant to dominant species in a particular region, pelagic community or ecosystem. A comprehensive understanding of a zooplankton species' existence can only be accomplished if those parameters (including other zooplankton taxa) affecting the species, and being affected by the respective species, are included in the assessments.

Another rationale for studying particular zooplankton species comes from their part in regulating biogeochemical cycling, biomass, and species diversity of marine ecosystems. Zooplankton are a major link in marine food webs and integral to nutrient and carbon cycling. For example, protozooplankton and small-size metazoans (small species and developmental stages) contribute greatly to biogeochemical fluxes in epipelagic waters over a wide latitudinal range. Small 
metazooplankton taxa (e.g. Oithona, Oncaea and small calanoids) can affect processes underlying marine ecosystem function because of their numerical or biomass dominance and their critical role as intermediaries between the classical and microbial food webs (Gonzalez et al. 1994). Changes in marine ecosystems, due to either natural or human-induced variability, could be observed through changes in communities of marine zooplankton, including composition, diversity and abundance.

\section{Zooplankton taxa of significance}

Examples of marine zooplankton taxa that could be considered for study include the copepod Calanus finmarchicus, a dominant species in part of the North Atlantic, and Calanoides carinatus from the northwestern Indian Ocean and ocean margins of Africa. The TransAtlantic Study of Calanus finmarchicus (TASC) was an initial effort in an attempt to perform a specieslevel study, as was the Subarctic Pacific Ecosystem Research (SUPER) study, which focused mainly on 3 species of the genus Neocalanus (Miller 1993).

The small copepod genus Oithona occurs ubiquitously and abundantly in the sea, from estuaries to the open ocean and from tropical to polar regions (e.g. Paffenhöfer 1993, Nielsen \& Sabatini 1996). In the Southern Ocean production of $O$. similis may be higher than each of the other zooplankton species there (Fransz \& Gonzalez 1995). The small copepod genus Oncaea, which is ubiquitous except in estuaries, can be as abundant as Oithona, and at times the dominant zooplankton taxon (e.g. Antarctic waters, Metz 1998). The potential significance of such small copepod genera in the oceans' pelagic communities and biogeochemical cycles has only been recognized during the past several years, because these organisms had not been collected quantitatively earlier due to the use of coarse net meshes.

The appendicularian genus Oikopleura is also broadly distributed and is characterized by extraordinary growth rates and short generation times (Deibel 1998, Hopcroft et al. 1998). The salp Thalia democratica occurs circumglobally in neritic subtropical waters and is known for the fastest growth rates of any metazoan (Heron 1972). Larger Salpa spp. can also occur in high abundance and produce large, fast-sinking faecal pellets. The euphausiid Euphausia superba is the dominant metazooplankton species in the Antarctic Ocean (e.g. Hopkins 1985), but its interannual variability is large and alternates with high abundances of salps $S$. thompsoni depending on ice cover. Oligotrich ciliates such as the genus Strombidium and other genera consume numerous species of nanoflagellates, which, in turn, are major consumers of primary production and bacterial secondary production.

Suitable study subjects are not limited to these examples. Selection of 'target' species should certainly require that they be major players in a significant ecosystem. Beyond that, rewarding target species are those that permit an integrative study through many levels of analysis from evolutionary ecology to molecular biology. Therefore, other criteria might include amenability to culture and information presently available in the literature.

\section{Model development}

Development and application of suitable models should play a significant part in the future species-level and hot spot studies. A recent workshop (US GLOBEC 1994) specifically recommended the following types of marine zooplankton models: (1) models based on the mechanisms that underlie animal behavior; (2) nested models that allow transfer of information between individuals and populations; and (3) detailed mechanistic models for a limited number of species. These suggestions include a large part of the integrated research suggested earlier in this section but also aspects related to zooplankton hot spots. Advances in the modeling of MZC1 Issue 1 have been made during the past $11 \mathrm{yr}$. For example, some individual-based models include small-scale behavior (Metridia lucens; Batchelder \& Williams 1995). Usually the behavior of zooplankton in models is in the form of simple swimming and/or migration responses to changes in environmental conditions, such as temperature, salinity or light (e.g. Dekshenieks et al. 1996). Models that include parameterizations of specific zooplankton motion behavior (e.g. drifting vs directed swimming), specific feeding behavior (e.g. feeding current vs attachment to particles vs swimming) and their interactions are only now starting to be developed. This direction in marine zooplankton modeling requires detailed experimental observations simulating environmental conditions as closely as possible.

Since MZC1, there has been an emphasis on the development of coupled physical-biological models (Table 1: Hofmann \& Lascara 1998, Carlotti et al. 2000). Advances in ocean circulation modeling have resulted in improved simulations of flow fields at nearly all scales. Long-term predictability of physical variables has advanced (e.g. Griffies \& Bryan 1997, Robinson et al. 1998), as have data assimilation methods for biological and ecological data (Lawson et al. 1995). To date, parameterization of zooplankton in circulation-biological models is usually in terms of average population characteristics for functional groups (e.g. Fasham et al. 1990) and or specific species (e.g. Moisan et al. 1996, Miller et al. 1998). 
Future models will require not only improvements in the representation of physics but also species-specific performances of the respective abundant zooplankton genera/species. Nested models that include parameterizations of individual and population processes have not been developed. They will require better field and experimental measuring capability, and advances in computer resources.

Any environmentally oriented species-level model will have to be interdisciplinary. Species-level models and hot spot models both occur in an environment affected by physical variables and numerous biological and chemical parameters, usually including several other zooplankton species as well, because no pelagic environment exists where one zooplankton species is exclusively abundant.

\section{Zooplankton and biogeochemical cycles}

Zooplankton directly affect the elemental stoichiometry and material fluxes between particulate and dissolved matter through various processes associated with the selective consumption and subsequent processing of their food resources. The most widely recognized link to biogeochemical fluxes is the repackaging of digestive by-products into fast sinking fecal pellets by relatively large animals (Noji 1991). Given the full spectrum of pelagic consumers (including protists) and the extent of their interactions within food webs, however, this is by no means the only way in which zooplankton can regulate the efficiency of the biological carbon pump or influence elemental cycles.

In the subsections below, we briefly consider the implications of zooplankton-mediated processes in modifying sinking particulate fluxes, in recycling and distributing inorganic and organic materials throughout the water column, and in determining the complex dynamics of food-web structure and trophic flows. Implicit in this discussion is a necessary progression of approaches that might begin with simple theory and experimental studies in bottles, but must extend to measurable phenomena in natural settings and system-level coupled models.

\section{Modification of the downward POM flux}

To achieve a mechanistic understanding of the decrease in particulate organic fluxes with depth, both within and below the euphotic zone, we need to know to what extent this decrease is due to the activities of zooplankton versus other consumers such as bacteria (Banse 1990) or physical/chemical processes. Furthermore, we need to know the rates and selectivities of zooplankton in modifying the chemical makeup of sinking particulate organic matter (POM) (Wakeham \& Lee 1993). Since most of the downward POM flux is in the form of relatively large particulates (fecal pellets and aggregates; Fowler \& Knauer 1986), future research must also address how zooplankton find and colonize such particles and how fast they consume them (Kiørboe 2000). First, however, we ought to find out which proto- and metazooplankton taxa are the main colonizers and feeders. Since grazing processes can also stimulate the metabolic activity of bacteria, and in turn the microbial role in particle disaggregation, this is an area of research that potentially involves synergistic influences of micro- and macro-consumers that are no less complicated than foodweb interactions in the epipelagic zone.

One exciting possibility for investigating how zooplankton modify the quality of the sinking POM is the use of biomarkers to distinguish organic matter sources and alteration processes (e.g. Brasell 1993, Wakeham \& Lee 1993). Progress in this area is presently limited, however, by the relative scarcity of unique biomarkers for phytoplankton prey, notable exceptions being dinosterol for dinoflagellates and long-chain alkenones for certain haptophytes (Brassell 1993). There are, however, virtually no biomarkers for zooplankton. The situation is further complicated by rapid digestive and biosynthetic alteration of dietary organic matter by the zooplankton themselves, as well as their assemblages of gut flora. Consequently, zooplankton nutritional physiologists need to collaborate closely with organic biogeochemists and microbiologists in developing useful new biomarkers for studying the fate of organic matter.

Numerous previous studies have focused on the role of zooplankton feeding on the packaging and vertical flux of particulate organic materials (Noji 1991, Feinberg \& Dam 1998). Much less effort has been directed at examining the impacts of zooplankton on the recycling of biogenic materials in the upper water column. By influencing the efficiency of recycling, zooplankton plays a critical role in determining the rate of regenerated production. This provides a direct linkage between zooplankton, primary production, and biogeochemical cycles. Thus, future studies should place greater emphasis on the mechanisms and processes by which zooplankton recycle nutrients and organic matter.

\section{Dissolved inorganic and organic matter (DIM and DOM): recycling and export}

A multi-level protistan grazing chain is the dominant trophic pathway in most open-ocean food webs, its length ensuring that primary production will largely be recycled rather than transferred to larger animals or 
exported. Although less important in absolute rates of material cycling, larger animals have the unique ability, in such deep-water systems, to deposit their metabolic by-products several hundreds of meters deeper than their food source in the euphotic zone. In addition, the active flux of both inorganic and organic carbon and nitrogen due to diel vertical migrators and the mortality of migrators below the pycnocline can significantly increase the exported production (Longhurst et al. 1989, Dam et al. 1995, Zhang \& Dam 1997). Data on this topic remain scarce, however. Further studies along gradients of latitude and productivity, similar to that of Ikeda (1985), are essential to establish global generalizations of the role of migrator-mediated fluxes of DIM and DOM.

A related realization is that zooplankton-generated DOM may be as important as that of phytoplankton in enhancing bacterial biomass and productivity (Hygum et al. 1997, Strom et al. 1997). These observations suggest several questions for future research: (1) What are the roles of zooplankton in supporting the microbial loop, and are they fundamentally different for protistan versus metazoan consumers? (2) What is the relative importance of alternate mechanisms of DOC production by zooplankton (e.g. excretion, sloppy feeding, fecal leaching) in the economy of the sea? (3) Is the biochemical composition of the DOC produced by zooplankton different from that produced from algal exudation, and if so, what are the consequences for bacterial production?

Additionally, we need to understand in much greater detail how direct grazing and the altered digestive products of zooplankton influence specific elemental cycles and greenhouse-relevant gases. Some challenges related to this topic include studies of zooplankton gut and fecal pellets as a habitat for anaerobic processes such as methanogenesis (Tilbrook \& Karl 1995), grazing influences on DMS production and transformations (Dacey \& Wakeham 1986, Wolfe \& Steinke 1996, Tang et al. 2000), and grazer control of the redox states and bioavailability of trace elements (Barbeau \& Moffett 2000).

\section{Community structure and food-web dynamics}

Within the context of a broad trophic network that varies in time and space, the interactions of producers and consumers have profound consequences for the biogeochemistry of the oceans. Differences in the coupling of production and grazing processes give rise, for instance, to large regional and seasonal variations in the magnitudes of phytoplankton standing stocks (blooms), nutrient utilization and recycling efficiencies, and export ratios. Two questions related to foodweb dynamics seem to be particularly important to a mechanistic understanding of oceanic biogeochemistry: (1) What are the roles of grazing and predation in controlling growth of populations and maintaining ecosystem stability in the open ocean (e.g. Frost \& Franzen 1992, Landry et al. 1997)? (2) How should food-web interactions be nested in models of biogeochemical cycles (Legendre \& Rassoulzadegan 1996, Verity \& Smetacek 1996)?

To answer question (1), we need experimental studies to validate and define the operational rules of potentially important regulatory mechanisms (e.g. Department of Energy 1994). For example, are lower limits of microbial population abundances set directly by protistan grazing thresholds, as assumed without sound supporting evidence in most models (Strom et al. 2000), indirectly by more complex cascading influences of higher-order consumers (Calbet \& Landry 1999), or by mechanisms as yet unappreciated? Related to this topic, we also must begin to understand when environmental factors can lead to large abundances of zooplankton with unique capabilities regarding phytoplankton control and export (e.g. salps, see also species level and hot spots) or whose secreted tests or shells can comprise significant geochemical pools and fluxes (foraminifera, radiolaria, pteropods).

Empiricists need to work closely with modelers as recommended in US GLOBEC (1994). One of the main frictions in such interactions involves the modeller's desire to reduce the problem to its simplest terms and the empiricist's desire to reproduce detailed behaviors of recognizable organisms and ecosystems. Zooplanktologists can contribute to modelling efforts by participating in the selection of model variables and processes and by lending their expertise to parameterization. In addition to challenging the modeller's structures and parameter values, zooplankton ecologists ought to appreciate the modeller's need for appropriate data sets and experimental results to validate key mechanisms as well as the system's natural dynamics.

\section{CONCLUSIONS}

The 3-day MZC2 was an interdisciplinary attempt to evaluate which issues would be of significance in future marine zooplankton studies. The 3 new issues that emerged from discussions focused on (1) zooplankton hot spots, (2) species-level interactions, and (3) biogeochemical cycling. These 3 foci complement the 7 issues addressed at MZC1 $11 \mathrm{yr}$ ago, which will continue to be major issues in the decades to come. This document is based on the urgent need to comprehend the function of biological processes in the ocean, and to enhance the recent pace of progress. Future major advances, not just in marine zooplankton re- 
search but in biological oceanography sensu strictu towards understanding community and eventually ecosystem functioning, and its variability, will be a function of setting priorities. We will not be able to develop a solid predictive capability on the significance of zooplankton in the pelagic environment, and therefore a general understanding of its functioning, until we can determine the mechanisms of the zooplankton's contribution (e.g. Aebischer et al. 1990). Determining such mechanisms and developing predictive capabilities depends on (1) continuous long-term observations not just on abundant zooplankton taxa but also of the major physical, chemical and biological variables governing their occurrence, distribution and abundance, (2) in situ rate quantifications of feeding, growth, mortality etc., accompanying the long-term observations, and (3) parallel interdisciplinary modeling (e.g. Hofmann \& Lascara 1998, Carlotti et al. 2000).

Acknowledgements. This colloquium was made possible by the commitment of more than 40 marine scientists who selflessly provided time and funds. The Skidaway Marine Science Foundation under the direction of Carol Megathlin supported the colloquium financially. The Georgia Coastal Center for Education provided meeting facilities. We gratefully acknowledge their support. This report was composed using a framework established at the meeting and repeatedly revised by several participants, who spent numerous hours to improving it.

\section{LITERATURE CITED}

Aebischer NJ, Coulson JC, Colebrook JM (1990) Parallel long-term trends across four marine trophic levels and weather. Nature 347:753-755

Ambler JW, Ferrari FD, Fornshell JA (1991) Population structure and swarm formation of the cyclopoid copepod Dioithona oculata near mangrove cays. J Plankton Res 13: 1257-1272

Ban S, Burns C, Castel J, Chaudron Y and 19 others (1997) The paradox of diatom-copepod interactions. Mar Ecol Prog Ser 157:287-293

Banse K (1990) New views on the degradation and the disposition of organic particles as collected by sediment traps in the open ocean. Deep-Sea Res 37:1177-1195

Barbeau K, Moffett JW (2000) Laboratory and field studies of colloidal iron oxide dissolution as mediated by phagotrophy and photolysis. Limnol Oceanogr 45:827-835

Batchelder HP, Williams R (1995) Individual-based modelling of the population dynamics of Metridia lucens in the North Atlantic. ICES J Mar Sci 52:469-482

Bollens SM, Frost BW (1991) Diel vertical migration in zooplankton: rapid individual response to predators. J Plankton Res 13:1359-1365

Brassell SC (1993) Applications of biomarkers for delineating marine paleoclimate fluctuations during the Pleistocene. In: Engel MH, Macko SE (eds) Organic geochemistry. Plenum Press, New York, p 699-738

Brodeur RD, Frost BW, Hare SR, Ingraham WJ Jr, Francis RC (1998) Interannual variations in zooplankton biomass in the Gulf of Alaska, and covariation with the California Current zooplankton biomass. EOS Trans 79:53
Buskey EJ, Stoecker DK (1989) Behavioral responses of the marine tintinnid Favella sp. to phytoplankton: influence of chemical, mechanical and photic stimuli. J Exp Mar Biol Ecol 132:1-16

Calbet A, Landry MR (1999) Mesozooplankton influences on the microbial food web: Direct and indirect trophic interactions in the oligotrophic open ocean. Limnol Oceanogr 44:1370-1380

Carlotti F, Wolf KU (1998) A Lagrangian ensemble model of Calanus finmarchicus coupled with a 1-D ecosystem model. Fish Oceanogr 7:191-204

Carlotti F, Giske F, Werner F (2000) Modeling zooplankton dynamics, In: Harris RP, Wiebe P, Lenz J, Skjodal HR, Huntley M (eds) ICES zooplankton methodology manual. Academic Press, San Diego, p 571-667

Cushing DH, Tungate DS (1963) Studies on a Calanus patch. I. The identification of a Calanus patch. J Mar Biol Assoc UK 43:327-337

Dacey JWH, Wakeham SG (1986) Oceanic dimethylsulfide: production during zooplankton grazing on phytoplankton. Science 233:1314-1316

Dam HG, Roman MR, Youngbluth MJ (1995) Downward export of respiratory carbon and dissolved organic nitrogen by dielmigrant mesozooplankton at the JGOFS Bermuda timeseries station. Deep-Sea Res I 42:1187-1197

Deibel D (1998) Feeding and metabolism of appendicularia. In: Bone Q (ed) The biology of pelagic tunicates. Oxford University Press, Oxford, p 139-149

Dekshenieks MM, Hofmann EE, Klinck JM, Powell EN (1996) Modeling the vertical distribution of oyster larvae in response to environmental conditions. Mar Ecol Prog Ser 136:97-110

Department of Energy (1994) Ocean Margins Program: water column and benthic boundary layer studies-scientific framework. Jahnke R, Verity $\mathrm{P}$ (eds) Department of Energy, Washington, DC

Doall MH, Colin SP, Strickler JR, Yen J (1998) Locating a mate in 3-D: the case of Temora longicornis. Phil Trans R Soc Lond B 353:681-689

Fasham MJR, Ducklow HW, McKelvie DS (1990) A nitrogenbased model of plankton dynamics in the oceanic mixed layer. J Mar Res 48:591-639

Feinberg LR, Dam HG (1998) Effects of diets on dimensions, density and sinking rates of fecal pellets of the copepod Acartia tonsa. Mar Ecol Prog Ser 175:87-96

Fessenden L, Cowles TJ (1994) Copepod predation on phagotrophic ciliates in Oregon coastal waters. Mar Ecol Prog Ser 107:103-111

Fowler SW, Knauer GA (1986) Role of large particles in the tranport and organic compounds through the oceanic water column. Prog Oceanog 16:147-194

Fransz HG, Gonzalez SR (1995) The production of Oithona similis (Copepoda:Cyclopoida) in the Southern Ocean. ICES J Mar Sci 52:549-555

Frost BW, Franzen NC (1992) Grazing and iron limitation in the control of phytoplankton stock and nutrient concentration: a chemostat analogue of the Pacific equatorial upwelling zone. Mar Ecol Prog Ser 83:291-303

Gonzalez SR, Kuipers BR, Fransz HG (1994) Mesozooplankton abundance, composition and copepod egg production from the polar front to the ice-edge during spring in the southern ocean. EOS Trans 75:177

Griffies SM, Bryan K (1997) Predictability of North Atlantic multidecadal climate variability. Science 275:181-184

Hanson AK, Donaghay PL (1998) Micro- to fine-scale chemical gradients and layers in stratified coastal waters. Oceanography 11:10-17 
Haury LR, McGowan JA, Wiebe PH (1978) Patterns and processes in the time-space scales of plankton distributions. In: Steele JH (ed) Spatial pattern in plankton communities. NATO Conference Series, Series IV: Marine Sciences, Plenum Press, New York, p 277-327

Herman AW, Sameoto DD, Longhurst AR (1981) Vertical and horizontal distribution patterns of copepods near the shelfbreak south of Nova Scotia. Can J Fish Aquat Sci 38: 1065-1076

Heron AC (1972) Population ecology of a colonizing species: The tunicate Thalia democratica. I. Individual growth rate and generation time. Oecologia 10:269-293

Hofmann EE, Lascara CM (1998) Overview of interdisciplinary modeling for marine ecosystems. In: Brink $\mathrm{KH}$, Robinson AR (eds) The sea, Vol 10. John Wiley \& Sons, Inc., New York, p 507-540

Holliday DV, Pieper RE, Greenlaw CF, Dawson JK (1998) Acoustical sensing of small-scale vertical structures in zooplankton assemblages. Oceanography 11:18-23

Hopcroft RR, Roff JC, Bouman HA (1998) Zooplankton growth rates: the larvaeceans Appendicularia, Fritillaria and Oikopleura in tropical waters. J Plankton Res 20:539-555

Hopkins TL (1985) Food web of an Antarctic midwater ecosystem. Mar Biol 89:197-212

Hygum BH, Petersen JW, Søndergaard M (1997) Dissolved organic carbon released by zooplankton grazing activitya high-quality substrate pool for bacteria. J Plankton Res 19:97-111

Ikeda T (1985) Metabolic rates of epipelagic marine zooplankton as a function of body size and temperature. Mar Biol 104:1-11

Irigoien X, Head R, Klenke U, Meyer-Harms B, Harbour D, Niehoff B, Hirche HJ, Harris R (1998) A high frequency time series at weathership $M$, Norwegian Sea, during the 1997 spring bloom: feeding of adult female Calanus finmarchicus. Mar Ecol Prog Ser 172:127-137

James MR, Hall JA (1995) Planktonic ciliated protozoa: their distribution and relationship to environmental variables in a marine coastal ecosystem. J Plankton Res 17:659-683

Jonasdottir SH, Fields D, Pantoja S (1995) Copepod egg production in Long Island Sound, USA, as a function of the chemical composition of seston. Mar Ecol Prog Ser 119:87-98

Kils U (1990) On the micro-structure of micro-layers. Results of an in situ zooplankton counter. EOS Trans 71:94

Kils U (1992) The ecoSCOPE and dynIMAGE: microscale tools for in situ studies of predator-prey interactions. Arch Hydrobiol Beih Ergeb Limnol 36:83-96

Kimoto K, Nakashima J, Morioka Y (1988) Direct observations of copepod swarm in a small inlet of Kyushu, Japan. Bull Seikai Reg Fish Res Lab 66:41-58

Kiørboe T (2000) Colonization of marine snow aggregates by invertebrate zooplankton: abundance, scaling, and possible role. Limnol Oceanogr 45:479-484

Kleppel GS (1993) On the diet of calanoid copepods. Mar Ecol Prog Ser 99:183-195

Kleppel GS (2001) The nutrition of zooplankton. Workshop Proceedings. University of South Carolina, Columbia

Landry MR, Barber RT, Bidigare RR, Chai F and 9 others (1997) Iron and grazing constraints on primary production in the central equatorial Pacific: an EqPac synthesis. Limnol Oceanogr 42:405-418

Lasker R (1975) Field criteria for survival of anchovy larvae: the relation between inshore chlorophyll maximum layers and successful first feeding. Fish Bull 73:453-462

Lawson LM, Spitz YH, Hofmann EE, Long RB (1995) A data assimilation technique applied to a predator-prey model. Bull Math Biol 57:593-617
Legendre L, Rassoulzadegan F (1996) Food-web mediated export of biogenic carbon in oceans: hydrodynamic control. Mar Ecol Prog Ser 145:179-193

Liang D, Uye S, Onbe T (1996) Population dynamics and production of the planktonic copepods in a eutrophic inlet of the Inland Sea of Japan. I. Centropages abdominalis. Mar Biol 124:527-536

Lindeque PK, Harris RP, Jones MB, Smerdon GR (1999) Simple molecular method to distinguish the identity of Calanus species (Copepoda: Calanoida) at any developmental stage. Mar Biol 133:91-96

Longhurst AR, Bedo AW, Harrison WG, Head EJ, Sameoto DD (1989) Vertical flux of respiratory carbon by oceanic diel migrant biota. Deep-Sea Res 36:1705-1719

Mackas DL, Denman KL, Abbott MR (1985) Plankton patchiness: biology in the physical vernacular. Bull Mar Sci 37: 652-674

MZC1 (Marine Zooplankton Colloquium 1) (1989) Future marine zooplankton research - a perspective. Mar Ecol Prog Ser 55:197-206

Marshall SM, Orr AP (1972) The biology of a marine copepod. Springer-Verlag, Berlin

Metz C (1998) Feeding of Oncaea curvata (Poecilostomatoida,Copepoda). Mar Ecol Prog Ser 169:229-235

Miller CB (1993) Pelagic production processes in the Subarctic Pacific. Prog Oceanogr 2:1-15

Miller CB, Lynch DR, Carlotti F, Gentleman W, Lewis CVW (1998) Coupling of an individual-based population dynamic model of Calanus finmarchicus to a circulation model for the Georges Bank region. Fish Oceanogr 7:219-234

Miralto A, Barone G, Romano G, Poulet SA, Ianora A, Russo GL, Buttino I, Mazzarella G, Laabir M, Cabrini M, Giacobbe MG (1999) The insidious effect of diatoms on copepod reproduction. Nature 402:173-176

Mischke U (1994) Influence of food quality and quantity on ingestion and growth rates of three omnivorous heterotrophic ciliates. Mar Microb Food Webs 8:125-143

Moisan JR, Hofmann EE, Haidvogel DB (1996) Modeling nutrient and plankton processes in the California coastal transition zone. 2. A threedimensional physical-bio-optical model. J Geophys Res 101:22677-22691

Neill WE (1990) Induced vertical migration in copepods as a defense against invertebrate predation. Nature 345: 524-526

Niehoff B, Klenke U, Hirche HJ, Irigoen X, Head R, Harris R (1999) A high- frequency time-series at Weathership $M_{\text {, }}$ Norwegian Sea, during the 1997 spring bloom: the reproductive biology of Calanus finmarchicus. Mar Ecol Prog Ser 176:81-92

Nielsen TG, Sabatini M (1996) Role of cyclopoid copepods Oithona spp. in North Sea plankton communities. Mar Ecol Prog Ser 139:79-93

Nielsen T, Satapoomin S, Hansen B, Sabatini M (1999) The role of Oithona spp. in arctic, temperate and tropical ecosystems. ASLO Meeting, Santa Fe, NM, 1-5 February 1999. American Society of Limnology and Oceanography, Waco, TX

Noji TT (1991) The influence of macrozooplankton on vertical particulate flux. Sarsia 76:1-9

Ohman MD, Wood SN (1995) The inevitability of mortality. ICES J Mar Sci 52:517-522

Omori M, Hamner WM (1982) Patchy distribution of zooplankton: behavior, population assessment and sampling problems. Mar Biol 72:193-200

Paffenhöfer GA (1993) On the ecology of marine cyclopoid copepods (Crustacea, Copepoda, Cyclopoida). J Plankton Res 15:37-55 
Paffenhöfer GA, Lee TN, Sherman BK (1987) Summer upwelling on the southeastern continental shelf of the USA during 1981. Abundance, distribution and patch formation of zooplankton. Prog Oceanogr 19:403-436

Paffenhöfer GA, Strickler JR, Lewis KD, Richman S (1996) Motion behavior of nauplii and early copepodid stages of marine planktonic copepods. J Plankton Res 18: 1699-1715

Peterson WT, Tiselius P, Kiørboe T (1991) Copepod egg production, moulting and growth rates, and secondary production, in the Skagerrak in August 1988. J Plankton Res 13:131-154

Pohnert G (2000) Wound-activated chemical defense in unicellular planktonic algae. Angew Chem Int Ed 39: 4352-4354

Price HJ (1989) Swimming behavior of krill in response to algal patches: a mesocosm study. Limnol Oceanogr 34: 649-659

Robinson AR, Lermusiaux RFJ, Sloan NQ III (1998) Data assimilation. In: Brink KH, Robinson AR (eds) The sea, Vol 10. John Wiley \& Sons, Inc., New York, p 541-594

Roemmich D, McGowan J (1995) Climatic warming and the decline of zooplankton in the California Current. Science 267:1324-1326

Smith S, Roman M, Prusova I, Wishner K, Gowing M, Codispoti L, Barber R, Marra J, Flagg C (1998) Seasonal response of zooplankton to monsoonal reversals in the Arabian Sea. Deep-Sea Res II 45:2369-2403

Strom SL, Benner R, Dagg MJ (1997) Planktonic grazers are a potentially important source of marine dissolved organic carbon. Limnol Oceanogr 42:1364-1374

Strom SL, Miller CB, Frost BW (2000) What sets lower limits to phytoplankton stocks in high-nitrate, low-chlorophyll regions of the open ocean. Mar Ecol Prog Ser 193:19-31

Tang KW, Visscher PT, Dam HG (2000) DMSP-consuming bacteria associated with the calanoid copepod Acartia tonsa (Dana). J Exp Mar Biol Ecol 256:185-198

Tang X, Stewart K, Vincent L, Huang H, Marra M, Gallager SM, Davis CS (1998) Automatic plankton image recognition. Artif Intell Rev 12:177-199

Editorial responsibility: Otto Kinne (Editor), Oldendorf/Luhe, Germany
Tilbrook BD, Karl DM (1995) Methane sources, distributions and sinks from California coastal waters to the oligotrophic north Pacific gyre. Mar Chem 49:51-64

Ueda H, Kuwahara A, Tanaka M, Azeta M (1985) Underwater observations on copepod swarms in temperate and subtropical waters. Mar Ecol Prog Ser 11:165-171

US GLOBEC (1994) Secondary production modeling workshop report. US Global Ocean Ecosystem Dynamics, Report No. 13, US GLOBEC, Berkeley, CA

Uye S, Sano K (1995) Seasonal reproductive biology of the small cyclopoid copepod Oithona davisae in a temperate eutrophic inlet. Mar Ecol Prog Ser 118:121-128

Verheye HM, Richardson AJ, Hutchings L, Marska G, Gianakouras D (1998) Long-term trends in the abundance and community structure of coastal zooplankton in the southern Benguela system, 1951-1996. S Afr J Mar Sci 19: 317-332

Verity PG, Smetacek V (1996) Organism life cycles, predation and the structure of marine pelagic ecosystems. Mar Ecol Prog Ser 130:277-293

Wakeham SG, Lee C (1993) Production, transport and alteration of particulate organic matter in the marine water column. In: Engel MH, Macko SE (eds) Organic geochemistry. Plenum Press, New York, p 145-169

Werner FE, Page FH, Lynch DR, Loder JW, Lough RG, Perry RI, Greenberg DA, Sinclair MM (1993) Influences of mean advection and simple behavior on the distribution of cod and haddock early life stages on Georges Bank. Fish Oceanogr 2:43-64

Wishner KF, Schoenherr JR, Beardsley R, Chen C (1995) Abundance, distribution and population structure of the copepod Calanus finmarchicus in a springtime right whale feeding area in the southwestern Gulf of Maine. Cont Shelf Res 15:475-507

Wolfe GV, Steinke M (1996) Grazing-activated production of dimethyl sulfide (DMS) by two clones of Emiliana huxleyi. Limnol Oceanogr 41:1151-1160

Zhang X, Dam HG (1997) Downward export of carbon by diel migrant mesozooplankton in the central equatorial Pacific. Deep-Sea Res II 44:2191-2202

Submitted: December 9, 2000; Accepted: August 2, 2001 Proofs received from author(s): October 17, 2001

\title{
Erratum
}

\section{Flow and particle distributions in a nearshore seagrass meadow before and after a storm}

\author{
T. C. Granata ${ }^{1, *}$, T. Serra ${ }^{2}$, J. Colomer ${ }^{2}$, X. Casamitjana ${ }^{2}$, C. M. Duarte ${ }^{1, * *}$, E. Gacia ${ }^{1}$, J. K. Petersen ${ }^{3}$ \\ ${ }^{1}$ Centre d'Estudis Avançats de Blanes, C. Santa Bàrbara s/n, 17300 Blanes (Girona), Spain \\ ${ }^{2}$ Environmental Physics, Department of Physics, University of Girona, Campus de Montilivi, 17071 Girona, Spain \\ ${ }^{3}$ National Environmental Research Institute, Frederiksborgvej 399, 4000 Roskilde, Denmark
}

Present addresses:

*Ecological Engineering Program, The Ohio State University, CEEGS 470 Hitchcock Hall 2070 Neil Avenue, Columbus, Ohio 43210-1275, USA. E-mail: granata.6@osu.edu

**Instituto Mediterraneo de Estudios Avanzados, C. Valldemossa km 7.5, 07071 Palma de Mallorca, Spain
- J. K. Petersen was accidentally omitted from the list of authors. Also, the first author's e-mail address has been updated. The corrected list of authors and their addresses is given here. 